\title{
THE COLLECTING AND REMITTING TRANSACTIONS OF A COOPERATIVE MARKETING CORPORATION
}

\author{
A. LAdRU JENSEN*
}

An agricultural cooperative marketing association is a unique business unit, consisting of a non-profit corporation which is bound by contract ${ }^{1}$ to its associated producer-members, who as multiple principals ordinarily use such entity as their agent ${ }^{2}$ through and by which they secure the advantages of combined, efficient, cost marketing of their family-farm products with limited liability to themselves. Some courts have observed that the statutes authorizing the incorporation of agricultural cooperative associations create a statutory non-profit agency and impose a statutory obligation on the cooperative to operate solely for the profit of its patrons as producers. ${ }^{3}$

\section{The Cooperative as Agent or Purchaser}

Until recently, nearly all of the organization documents of cooperative marketing corporations, including the marketing contracts with members, have evidenced some confusion as to the agency or sales relationship intended to be created. In spite of conflicting statements usually found in the by-laws and marketing contracts to the effect that the cooperative corporation is to be the non-profit agent of the patron, but that the patron sells his products to it and transfers title upon delivery of the products, the cases generally have held that the cooperative is the agent of its patrons. ${ }^{4}$ Some of the cases hold that the cooperative is "an agent or trustee for

- Professor of Corporation Law at the University of Utah. Consultant on Legal Education to the American Institute of Cooperation and co-chairman of the Committee on Classification and Terminology of Cooperative Corporation Law of the American Bar Association.

1 The contract between the patron-member and his cooperative marketing corporation is found in the articles of incorporation, or the by-laws, and usually in a marketing contract. See Frank Evans and E. A. Stordyr, The Law of Agricultural Cooperative Marketing 86-158 (i937).

${ }^{2}$ For a comprehensive survey of the (multiple) principal and (common) agent relationships created: bargaining agent only, an agent-bailee, or an agent having a trust or agency title, see Jensen, Cooperative Corporation Lasw on the Marketing Transaction, 22 WAsH. L. REV. I-18 (1947).

'In San Joaquin Valley Poultry Producers' Ass'n v. Commissioner, 136 F. 2d 382 (C.C.A. 9th 1943), the court quoted the statutory obligation to operate without profit under $\$ 1192$ of the California Agriaultural Code and also noted a by-law provision to the same effect. A contract with a non-member which authorized the deduction of a diseretionary portion of his pro rata net proceeds of sales for the purpose of building up a general reserve has been held ultra vires under the New York statute requiring service to non-members to be at cost. Dairymen's League Cooperative Ass'n, Inc. v. Holmes, 207 App. Div. 429, 202 N.Y.S. 663 (I924), aff'd, 239 N. Y. 503, I47 N. E. I7I (I924).

tOwen County Burley Tobacco Society v. Brumback, $128 \mathrm{Ky} .137,107$ S.W. 710 (1908), California Raisin Growers' v. Abbott, I60 Cal. 6or, II7 Pac. 767 (I9rr), Phez Company v. Salem Fruit Union, 20I Ore. 514, 201 Pac. 222 (I92I), Kelowna Growers' Exchange v. De Caqueray, 7o D.I.R. 865 (1922), Poultry Producers of Southern California v. Barlow, I89 Cal. 278, 208 Pac. 93 (I922), 
its patrons," and one late case says that it acts "as trustee" for "the members as settlors."6

There are, however, a few earlier cases which held that the dominant language of sale in the organization papers and the conduct of the parties evidenced a relationship of selling patron and purchasing cooperative. ${ }^{7}$ The later trend of decisions is almost uniformly to construe cooperative marketing contracts as making the cooperative an agent or agent-trustee for its members except in the few instances where the parties under statutory authorization have clearly abandoned the agency relationship and expressly adopted by agreement and practice the seller-purchaser relationship for definite economic advantages. ${ }^{8}$

In Canada, the recent Royal Commission on Cooperatives found considerable variation in the details of contract and property relationship between cooperatives and their patrons. ${ }^{\ominus}$ The Commission concluded, however, that Canadian agricultural cooperatives were chiefly of two types, the agency-consignment type $e^{10}$ and the sales type. ${ }^{11}$

Haarparinne v. Butter Hill Fruit Growers' Ass'n, 122 Me. 138, 119 Atl. 116 (1922), Oregon Growers Coop. Ass'n v. Lentz, ro7 Ore. 56r, 212 Pac. 811 (r923), Kansas Wheat Growers' Ass'n v. Board of Commissioners, I19 Kan. 877, 24r Pac. 466 (1925), Tobacco Growers Co-op. Ass'n v. L. Harvey \& Son Co., I89 N. C. 494, I27 S. E. 545, 547 (1925), Dark 'Tobacco Growers' Co-op. Ass'n v. Riobertson, 84 Ind. App. 5I, I50 N. E. I06, II2 (I926), Johnson v. Staple Cotton Co-op. Ass'n, I $_{42}$ Miss. 312, 107 So. 2 (r926), City of Owensboro v. Dark Tobacco Growers' Ass'n, 222 Ky. 164, 300 S. W. 350 (1927), Mountain States Beet Growers' Marketing Ass'n v. Monroe, 84 Colo. 300, 269 Pac. 886 (1928), Rhodes v. Little Falls Dairy Co., 230 App. Div. 57I, 245 N.Y.S. 432 (1930), affd, 256 N. Y. 559, II7 N. E. 140 (I93I), Spencer Cooperative Live Stock Shipping Ass'n v. Schultz, 209 Wis. 344, 245 N. W. 99 (1932), Texas Certified Cottonseed Breeders' Ass'n v. Aldridge, I22 Tex. 464, 61 S. W. 2d 79 (1933), Pyrke v. Brudno, 243 App. Div. 493, 278 N.Y.S. 353 (1935), Georgia Milk Producers Confederation v. Atlanta, 185 Ga. 192, I94 S. E. 18x (1937), Inland Empire Rural Electrification, Inc v. Dep't of Public Service, 199 Wash. 527, 539, 92 P. 2d 258 (I939), Industrial Commission v. United Fruit Growers' Ass'n, 106 Colo. 223, 103 P. 2d 15 (1940), Bogardus v. Santa Ana Walnut Growers' Ass'n, 4I Cal. App. 2d 939, ro8 P. 2d 52 (x940), Department of Treasury v. Ice Service, Inc., 220 Ind. 64, 4I N. E. 2d 201 (r942), Bowles v. Inland Empire Dairy Ass'n, 53 F. Supp. 2ro (E.D. Wash. 1943).

'Bogardus v. Santa Ana Walnut Growers' Ass'n, 4r Cal. App. 2d 939, ro8 P. 2d 52 (1940), and San Joaquin Valley Poultry Producers' Ass'n v. Commissioner, 136 F. 2d 382 (C.C.A. 9th 1943).

${ }^{\circ}$ California and Hawaiian Sugar Refining Corporation, Ltd. v. Commissioner, I63 F. 2d 53r, 535 (C.C.A. 9th 2947 ).

7 Texas Farm Bureau Cotton Ass'n v. Stovall, II3 Tex. 273, 253 S. W. IIor (1923) (superseded by Texas Certified Cottonseed Breeders' Ass'n v. Aldridge, I22 Tex. 464, 61 S.W. 2d 79 (1933) holding agency); Neith Cooperative Dairy Products Ass'n v. National Cheese Producers' Federation, 217 Wis. 202, 257 N. W. 624 (1934).

${ }^{8}$ In Clinton Cooperative Farmers Elevator Ass'n v. Farmers Union Grain Terminal Ass'n, 223 Minn. 253, 26 N. W. 2d II7 (1947), the Grain Terminal Association purchased and resold the grain of its patrons so that it could get the mark-ups allowed by the Office of Price Administration upon resale transactions. The court approved the practice which placed grain marketing cooperatives in the same selling position as commission merchants and held that under a statute providing that a cooperative association conducting a commission business may, either as agent or otherwise, buy, sell, or deal in the products of its individual members or patrons, such association had the power to buy for its own account grair consigned to it for sale, notwithstanding an earlier statute forbidding commission merchants, either individual or corporate, from buying for their own account grain consigned to them for sale.

- Report of the Royal Commission on Cooperatives 20-22 (Ottawa, 1945).

10 "Some associations receive products as agents or on a consignment from their members and sometimes from non-members as well." Id. at 24 .

11 "Instead of accepting products on consignment, other marketing associations purchase products from members, and often non-members, and resell them sometime later." Id. at 25. 
The adjudicated cases in the United States show a great preponderance of agency-type agricultural cooperatives which operate, not merely as bargaining agents nor as agent-bailees of the patrons' products on consignment, but as selling agents taking a trust title to delivered products to accomplish the purposes of the agency. ${ }^{12}$

\section{Agency Plus Trust Relationships}

Many lawyers unfamiliar with the legal nature of the hybrid business unit called a cooperative corporation association are misled into believing that because title passes to the cooperative, and usually a cash advance of the going market price is made to the patron upon or soon after delivery, a sale has taken place. As was pointed out in the well reasoned case of Bowles v. Inland Empire Dairy Association, $^{13}$ the intention and agreement of the parties is not that an agreed price will be paid for the products delivered, but that the patron's pro rata share of the net proceeds of sale will be paid over to him. There is no price agreed upon; and an agreed price is an indispensable element of a sale according to the definition of that transaction in the Uniform Sales Act. ${ }^{14}$

A well reasoned case which shows that contract language of sale and transfer of title of the patron's products to the cooperative is compatible with the basic agency purposes of the cooperative marketing association statutes is Texas Certified Cottonseed Breeders' Association v. Aldridge, ${ }^{15}$ in which the Supreme Court of Texas said:

The farmers as a group form the association, and appoint it to act as their selling agent. They turn over to the association their commodities to be pooled and sold on the market to the best advantages. . . .

The contract upon this point [transfer of title] is clothed in the terminology of a sale. The relation of consignor and factor has been abandoned. The logical and practical object of the members, as expressed in the contract, is to clothe the transaction in the language of a sale for the purpose of permitting the exercise of all powers named in the contract rather than a consignment in order to enable the association to enter bona fide transactions free from the embarrassment arising out of an incomplete title. . . .

The members of the association, in order to promote their welfare, delivered their seed to the association. They constituted the association their agent with broad and exclusive powers to handle and sell their commodity. This was necessary to accomplish the very purposes for which it was created. It being the clear intention of the members to create a true cooperative marketing association, under the powers camerated by law and by the contracts, to perform certain services exclusively for its members, and to hold in the face of this intention that the delivery of the seed to the association was an absolute sale would destroy it as a cooperative marketing association. ${ }^{16}$

${ }^{12}$ See Jensen, Cooperative Corporation Law on the Marketing Transaction, 22 WASH. L. REv. 9-15 (1947), and Goldsmith, Passage of Title under Cooperative Marketing Contracts, I8 Ore. L. REv. I57-I74 (1939).

2853 F. Supp. 210,220 (E.D. Wash. 1943).

21 I Samuel Wilziston, The Law Governing Sales of Goods at Common Law and Under the UNIFORM SALES Act, \$I7I (2d ed. r924); "Uniform Sales Act, $\$ 1(2):$ A sale of goods is an agreement whereby the seller transfers the property in the goods to the buyer for a consideration called the price." II id. App. 1751. See also Note, Cooperative Marketing, 77 A.L.R. 413 (1932).

${ }_{10}^{122}$ Tex. 464,61 S. W. $2 d 79$ (1933). ${ }^{10}$ ld. at 82,83 . 
Since, as we have seen, the cooperatives are ordinarily the marketing agents of their members, what àre the duties of such cooperatives to account to their member patrons for net proceeds of sales, and what are the various types of remitting transactions now in vogue?

\section{Duties of a Collecting Agent}

It is a well established principle of agency law that an agent who is entrusted with the products of his principal for purposes of selling them, and who does not have express authority to collect, nevertheless has "implied authority to receive payment arising from the fact that the agent sold the goods for which the demand is due." 17

It is also well established agency law that a collecting agent has no implied authority to retain the funds collected, or to enter into contracts regarding them, or to deal with them as if they were his own. His duty is to transmit the collected funds with reasonable diligence to the principal, in the absence of some express agreement to the contrary. ${ }^{18}$

It, therefore, was rightly held in American Box Shook Export Association v. Commissioner" that the cooperative, which merely had an "informal understanding" with its stockholders that it would pay them all income after deducting expenses and a reserve for future claims, and which was not legally bound to pay over said net proceeds to its patron stockholders, was not their agent. In such a case, the cooperative was doing business for itself as a corporate principal and the net economic gains which it had no duty to remit to its stockholders were corporate income and therefore taxable as such.

However, a collecting agent who does have a legal duty to remit collected funds to his principals may in fact retain the proceeds longer than he should, and thus be guilty of negligence in remitting, ${ }^{20}$ or the agent may sometimes retain the funds collected and use them for his own benefit, intending to remit an equivalent' amount at some future time. This latter situation was found to exist in Rhodes $v$. Little Falls Dairy Company, ${ }^{21}$ which declared it to be the duty of a cooperative corporation operating as agent to account for the pro rata net proceeds of sales to its patron members on demand.

Before reviewing the Little Falls Dairy Company case, it is important to note the economic basis and legal nature of revolving-fund capital financing of cooperatives.

Except in times of war prosperity, farmers proverbially have little cash and not too much credit.22 This fact explains in part why most cooperatives are not suf-

${ }^{28}$ I Floyd R. Mechess, A TreatTse on the LaW of Agency 678, 5944 (I914).

${ }^{18}$ Id. at 692, 596r.

${ }^{19} 156$ F. 2 d 629 (C.C.A. 9th 1946). The company was incorporated to export box shook for its member stockholders.

${ }^{20}$ MECHEM, op. cit. supra note 17 , at 949 , \$1309.

${ }^{21} 245$ N.Y.S. 432 (1930); see also Texas Certified Cottonseed Breeders' Ass'n v. Aldridge, 122 'Tex. 464,6 I S. W. 2d 79 (1933).

${ }_{32}$ Roger W. BABSON, IF INFLATION COMES 2X4-215 (4th imp. I945). 
ficiently capitalized with permanent investment capital. It is almost universal practice that producer-members authorize their marketing cooperatives to retain, in the discretion of the board of directors, part of the net proceeds of sales for an interim period to provide requisite capital for the corporation. Thus the patron-principals temporarily waive their right to demand immediate pro rata remittances in cash.

\section{Revolving Fund for Capital Financing}

Mr. L. S. Hulbert has given an excellent statement of the revolving-fund plan of financing agricultural cooperative corporations: ${ }^{23}$

The problem of how equitably to capitalize a cooperative so that the capital furnished by a particular member will bear a direct relation to his patronage and ultimately will be returned to him is believed by many competent cooperative leaders to be solved best through use of the revolving-fund plan of financing.

Cooperatives commonly have begun business with a small amount of capital, which has been gradually increased from deductions or savings without giving to the respective patrons a clearly defined contingent right with respect to the sums that each by reason of his patronage has provided. ...

Broadly speaking, this plan is one under which, after sufficient capital has been accumulated to justify doing so, money supplied by current patrons or others for capital purposes is used to retire the oldest outstanding investments of patrons or others in its revolving fund.

In marketing associations, under this plan, money for capital purposes is obtained principally from retains or deductions on a percentage or a unit basis, or from the sale of certificates of various kinds. In purchasing associations, the major part of the capital is usually obtained from earnings or savings. . . .

The derivation of the name "revolving-fund plan" becomes more apparent when an association reaches the stage when the oldest investments of the patrons of previous years may be retired. It is only when an association reaches this stage that its revolving fund begins to revolve. Money which is thus furnished by the patrons of an association for capital purposes should be regarded by them as an investment in their own association and not as an additional expense. It cannot be overemphasized that it takes money to go into business. Farmers, when they form and operate a cooperative, are in business and should supply the required capital.

There is a wide latitude with respect to the terms and conditions which may be adopted for the revolving-fund plan of financing.

Accumulations or retains for capital purposes, under this plan of financing, should be at least recorded on the books of the association as credits in favor of the proper persons. Generally, associations issue certificates to evidence such funds. These certificates are sometimes referred to as "certificates of indebtedness," "revolving-fund certificates," "certificates of equity," or "certificates of interest." The terms and conditions of such certificates differ and the rights of the holders vary accordingly. ${ }^{24}$

\section{Duty to Account to Members}

A leading case which holds that a patron-principal is entitled to an accounting and prompt, full payment from his cooperative marketing agent is the Little Falls

23 L. S. Hulbert, Legal Phases of Cooperattve Associations (Farm Credit Administration, United States Dep't of Agriculture, Bull. No. 50, 1942). Mr. Hulbert is Chief of the Cooperative Bank and Ccoperative Research Section, Farm Crcdit Division, Office of the Solicitor, United States Department of Agriculture.

24 Id. at $276-277$. 
Dairy Company case, ${ }^{25}$ decided by the Supreme Court of New York in 1930.

The plaintiff dairyman had delivered his milk to the cooperative company from March 20, I929, until the bringing of his action some time in r930. The company had distributed all net proceeds of sales pro rata to its patrons for 1929 operations.

The marketing agreement provided that for the milk delivered the dairy company would "distribute to plaintiff his proportionate share of the earnings [net operating margins] of the company after deductions including a sufficient sum to provide for a reasonable return to the stockholders of the company, and a further sum for sufficient working. capital, improvement of plant, and reserves necessary for the successful operation of the business, according to the judgment of the directors."

Beginning January $\mathrm{x}$, I927, the company began reserving from net proceeds of sales sums for capital purposes, improvement of plant, and reserves apparently other than valuation or cost reserves, which it did not allocate to plaintiff and other patron-members, although apparently the records made such capital retains susceptible of pro rata allocation.

Plaintiff demanded payment of his full pro rata share of net proceeds of sales, and upon refusal of the company to comply with his demand he brought suit for accounting and payment. On appeal the Supreme Court held that the complaint stated a good cause of action. The court said in part:

The facts alleged in the complaint show a fiduciary relationship between the parties. It partakes in large measure of the nature of a joint venture, in which case an action in equity is maintainable for an accounting (Marston v. Gould, 69 N. Y. 220), and is not unlike that of an agent who has been intrusted with his. principal's money or property to be expended or dealt with for a specific purpose, in which case the agent is at all times amenable to the process of the court to show that his trust duties have been performed and the manner of his performance. Marvin v. Brooks, 94 N. Y. 7r; Hotel Register Co. of New York v. Osborne, 84 App. Div. 307, 82 N. Y. S. 6og.

"It is not necessary that there be a technical trust. Equity will take jurisdiction where there is a relation of agency and confidence and the agent has received property of the principal for which he refuses to account." Talmudic Literature Publishers, Inc. v. Lewin, 226 App. Div. I, 2, 234 N. Y. S. 164, I66.

It also clearly appears that something more than a computation according to set figures will be necessary before it can be determined whether or not defendant has made proper distribution to plaintiff and other producers in like situation in the amounts to which he and they are entitled.

In Johnson v. Staple Cotton Co-op. Ass'n (I926) $x_{42}$ Miss. 312, I07 So. 2, it was held that the cooperative marketing contract between the association and a member creates the relation of principal and agent; the association being a sales agency operating for the benefit of its members. In this case the court held that plaintiff was entitled to a disclosure and accounting as to insurance carried on the crops of its members; his crop of cotton having been destroyed by fire.

"It has always been within the jurisdiction of courts of equity to grant relief where legal remedies are inadequate, and it is evident that by reason of the peculiarity of the

${ }^{25} 245$ N.Y.S. 432 (I930). 
cooperative marketing plan, any legal remedy would be wholly inadequate." Arkansas Cotton Growers' Co-op. Ass'n v. Brown, 168 Ark. 504, 522, 270 S. W. 946, 953, IrIg.

There was a fiduciary relationship here; defendant was dealing with plaintiff's property. It was its duty to get the best price possible for it, to make such deduction from the proceeds for expenses and other items mentioned in the contract as were required in necessity and reason, and to return to plaintiff his share of the profits, [net operating margins] remaining, if such there were, based upon the milk that he furnished. These facts are not known to plaintiff, and can only be ascertained in an accounting by defendant. It seems to us that the complaint states a good cause of action for such relief.28

\section{Retaining Patronage Net Margins Without Accounting or Payment}

In the Little Falls Dairy Company case, the company contended that under the by-law allowing it, as agent, to retain "a further sum for sufficient working capital, improvement of plant, and reserves necessary for the successful operation of business, according to the judgment of the directors," it had secured a legal right to supply its capital needs without the need of accounting or payment over to, and investment back from, its patron-members.

The court held that this contention was not sound. The cooperative must account to its member patrons for all net proceeds of sales. The cooperative had denied the patron his legal rights by setting up an unallocated reserve for an indefinite period of time. It had retained his funds without full and clear terms as to its right of retention and thus denied his right of demand payment.

The heart of the legal, the practical, and indirectly of the tax, difficulties with cooperatives lies in such attempts to build up corporate capital (sometimes as reserves) without a complete and definite agreement as to the rights of the marketing patrons and the cooperative regarding those capital funds.

The difficulty is pertinently illustrated by a colloquy between one of the commissioners in the Royal Canadian Hearing on Cooperatives and Mr. Francis, attorney for the cooperatives, on the meaning of what had been referred to as "allocation" of net patronage proceeds. The transcript of the testimony reads:

Mr. Nadeav: (Commissioner) While we are on this subject, do you consider that an allocation is a payment, an obligation to pay?

Mr. Francis: (Attorney for cooperatives) Within the meaning of the section, yes on the interpretation I am giving.

MR. NADEAU: Under your own interpretation it would be a payment?

Mr. Francis: Yes.

Mr. NADEAU: But do you think that with the relationship which exists between debtor and creditor, the creditor is really paid when the debtor gives credit to him in his books? Is that real and actual payment?

Mr. Francis: I think in English law we call that a chose in action, that a chose in action is established on the allocation. ${ }^{27}$

It does seem that it is stretching logic too far to say that a book-entry admission

${ }^{20}$ Id. at $434,435,436$.

${ }^{27}$ XXXII Offichal Report of the Procendings of the Royal CoMmission on CoOperatties 7944 (Ottawa, 1945). 
by a debtor-agent of his indebtedness should be regarded as accounting and constructive payment to the creditor-principal.

\section{The Contract for Retention of Net Patronage Margins}

In spite of the liberal contractual by-law provision purporting to allow the Little Falls Dairy Company to retain net patronage proceeds for capital purposes, the court in that case declared that in a non-profit corporation patronage net margins constitute accumulated sums owing by the corporate agent-trustee to its principalbeneficiaries because of a legal relationship peculiar to the "cooperative marketing plan of doing business." Under this legal doctrine, the agent takes title to the funds collected with the consent of the principal, similarly as the cooperative took legal title to the patron's products pursuant to agreement with the agent. ${ }^{28}$

It is, therefore, only by reason of a contract right granted to the cooperative by its members in the articles, or by-laws, or marketing agreement that the corporation may legally retain any fraction of the patronage net margins for its capital purposes.

The appellate court left to the trial court upon retrial of the Little Falls Dairy Company case three questions for determination: first, the extent of the patronage net margins which could be lawfully retained under the particular contract; second, the method by which the corporation would account to the patrons for those net margins; and, third, the manner in which those net margins would be actually or constructively paid to the patrons.

In the absence of an express or implied-by-conduct agreement of the cooperative and its members covering these three questions, the courts have the duty of implying reasonable terms to establish the rights of the cooperative and of the patron in regard to retained patronage net margins.

\section{Accounting for and Paytng Final Amount Due Patron}

Even when agricultural marketing association statutes ${ }^{20}$ declare, as they usually do, that cooperatives must be organized as non-profit corporations, for the profit of their members as producers, the time for accounting and the manner and medium of payment are matters of contract between the parties.

The five chief methods of accounting for, and payment to patrons of, annual net proceeds of sales and savings may be classified as follows:

r. Payment in cash.

2. Payment in cash-equivalent, called by the regulations of the Internal Revenue Department "constructive payment." 30

${ }^{28}$ Fertile Co-operative Dairy Ass'n v. Huston, Irg F. 2 d 274 (C.C.A. 8th r94I), affirming 33 F. Supp. 712 (N.D. Iowa 1940), holds that a cooperative which acts as a business principal in dealing with non-member patrons and makes a profit on non-member business has taxable corporate income from non-member transactions.

${ }^{80}$ The Bingham Cooperative Marketing Act, Laws of Kentucky, c. $x, \$ 2$ (d) (r922) provides: "Associations organized hereunder shall be deemed 'non-profit,' inasmuch as they are not organized to make profit for themselves, as such, or for their members, as such, but only for their members as producers." See note 3 supra.

${ }^{30}$ Sec. 29.42-2 Regulations III of the Internal Revenue Department covering income not reduced 
3. An executory agreement to pay:

a. On demand of the patron-member,

b. At a time certain in the future, or

c. At some determinable future time; usually when in the bona fide judgment of the board of directors the capital needs of the corporation have been properly supplied by an adequate accumulation to the capital revolving fund.

4. An obligation ultimately to pay the patron, represented by "allocation" of prorated patronage net margins on the corporate books, and notice thereof to the patron.

5. An obligation ultimately to pay the patron, represented only by entries on the corporate books from which patrons' patronage net margins can be computed.

\section{Payment in Cash}

Occasionally a cooperative corporation may be found which has secured its corporate capital by the sale of stock and sometimes in part by the sale of bonds, in the customary manner by which private-profit corporations are capitalized. In such cases the cooperative can, and may, pay final patronage net margins in cash to its members within a reasonable time after the close of the fiscal year and upon completion of the annual accounting.

\section{Payment in Permanent Corporate Stock}

A case which illustrates constructive payment in permanent preferred stock is Paducah \& Illinois Railroad Company, decided by the Board of Tax Appeals in r925. ${ }^{31}$ In this case, three railroad companies caused this non-profit bridge company to be incorporated. The bridge company secured loan capital of five million dollars by the issuance of corporate bonds. With this capital, it erected a railroad bridge over the Ohio River for the use of its three patrons.

The three railroad companies agreed to pay certain charges for their use of the bridge. They also signed a continuing subscription agreement obligating them to purchase preferred stock in the bridge company out of net patronage margins which would accumulate in the treasury of the bridge company above the costs of operation. The bridge company agreed that it would operate at cost and would credit the balance of the payments for use of the bridge above costs of operation to the continuing subscriptions of the respective railroads to the preferred stock of the Paducah \& Illinois Railroad Company.

The parties also agreed that the capital secured from the investing of annual

to possession reads as follows: "Income which is credited to the account of or set apart for a taxpayer and which may be drawn upon by him at any time is subject to tax for the year during which so credited or set apart, although not then actually reduced to possession. To constitute receipt in such a case, the income must be credited or set apart to the taxpayer without any substantial limitation or restriction as to the time or manner of payment or condition upon which payment is to be made, and must be made available to him so that it may be drawn at any time, and its receipt brought within his own control and disposition. A book entry, if made, should indicate an absolute transfer from one account to another."

${ }^{8 x} 2$ B.T.A. IOOI (I925). 
patronage net margins in preferred stock was to be used to pay off and retire the outstanding bonds of the corporation and thus change its capital fund from loan capital to permanent investment capital as rapidly as net patronage margins were available to accomplish that purpose. Under this arrangement, the Board of Tax Appeals held that the patrons received constructive payment of the annual patronage net margins which they simultaneously reinvested in the permanent stock of the corporation and that the funds so handled never became income of the cooperative corporation. ${ }^{32}$

Many agricultural cooperatives have adopted a pattern of capital financing similar to that used by the Paducah \& Illinois Railroad Company. The patrons make a continuing contract, usually in the form of a company by-law, or membership contract, or both, by which they agree to furnish investment capital to the corporation, and the cooperative and its patrons mutually agree that the cooperative shall credit annual patronage net margins upon the continuing subscription contract of the patron to supply revolving capital to the corporation.

If it be agreed that patronage net margins shall be credited to loan capital instead of invested capital, the obligation of the cooperative to pay the patron is merely changed from an ordinary demand debt into a long-term obligation, or to a capital loan payable at a determinable future time. When the patronage net margins are credited to invested capital, the patron's legal position is changed from that of a creditor to that of an investor. It is important that by-laws should clearly delineate and differentiate these situations.

\section{Payment in Hybrm Securtiries}

Agricultural cooperative corporations have used many forms of incomplete agreements and documents to evidence the legal relationship between the cooperative and the patron in building up a capital revolving fund. The confusion which has existed, and still exists in too large a degree, has been well described by the late E. A. Stokdyk, formerly president of the Berkeley Bank for Cooperatives. He writes:

First of all, the terms used to describe members' capital equities and other instruments issued by membership cooperatives are many and varied. The following is a partial list: advance funds, revolving funds, withholdings repayable, reserve funds, certificates of interest, certificates of equity, members' investment, capital retains, growers' equity, and finance funds. Some associations merely carry members' capital equities as book credits, sending them a statement showing the amount of the book credits periodically.

The names used seldom describe the nature of the instruments. One must examine

${ }^{22}$ Ibid. The railroads incorporating a non-profit bridge company were the Chicago, Burlington \& Quincy R: R, the Nashville, Chattanooga \& St. Louis Ry., and the Illinois Central R. R. The question before the Board of Tax Appeals was whether the amounts credited to the purchase of preferred stock by the three railroad companies (\$95,238 in 1920 and $\$ 121,550$ in rg21) "constituted income or capital contributions during the years in question." The court held that under the contract of July, 1915, the payments by the railroad companies, above ordinary expenses, interest, taxes, depreciation, and dividends, which were credited to investment in capital of the bridge company and which the bridge company was required to pay to its patrons to operate on a non-profit basis, were not income to the corporation, but were capital contributions of its patrons. 
them and consult the articles and by-laws to determine their status. When one does, he frequently finds that their status is uncertain because they are not adequately described. Or he may find that a part or all of the items carried in the net worth section of the financial statement are in reality obligations of the association and not part of the net worth. For example, some associations have issued instruments with due dates to their members to evidence funds withheld to finance the association and classed the funds as net worth. Instruments with due dates, if short term, are notes; if long term, are bonds. The holders of such instruments are creditors. ... .

An instrument without a due date and subject to the rights of creditors is comparable to the preferred stock of a capital stock corporation. Those issued by a membership cooperative should be of this nature if financial soundness is desired and financial embarrassment is to be avoided.

Some capital stock associations have issued preferred stock with due dates, little realizing that these were in reality bonds, and have faced financial difficulty when the bonds fell due. On the other hand, some capital stock associations have issued instruments without due dates which they called notes when actually these instruments were in the nature of preferred stocks.

Much litigation has resulted from the issuance of instruments not well defined or adjudicated. These are termed hybrid securities. Membership cooperatives will avoid much confusion and litigation if they describe their members' capital equities adequately and make them of the nature of preferred stock of ordinary corporations. ${ }^{33}$

\section{Payment by Certificates of Indebtedness}

The relationship between the cooperative and its patron-members regarding annually accumulated patrons' net margins is not merely that of an ordinary debtorcreditor but rather is that of a debtor-agent to a creditor-principal. The agency creates a fiduciary relationship and an equitable duty upon the agent to account, as well as a legal duty to pay to the patron what is justly due him as his pro rata share of patronage net margins. ${ }^{34}$

In the absence of a contrary agreement as to time of payment, the cooperative's duty is to pay promptly; certainly upon demand of the member. ${ }^{35}$ This demand debt may be legally changed into a definite capital loan by an appropriate agreement embodied in a by-law or marketing agreement. A considerable number of agricultural marketing corporations issue to patrons certificates of indebtedness. These certificates usually provide that the claim of holders thereof are deferred to the claims of common creditors. A recent trend toward this type of cooperative capital financing is observable. These certificates may, by contract of the parties, be made payable on demand or at some definite time in the future, or may be made payable at the option of the board of directors, when in its judgment sufficient capital has been accumulated so that the oldest loans may be safely paid. It is the intent of the parties that a later cash payment will be made by revolving the capital loan fund, so that the oldest lenders will be paid first. If no definite time for payment

\footnotetext{
"E. A. Stokdyk, Financial Structure and Policies of Cooperatives 2-3 (American Institute of Cooperation, October, I945).

"See notes 21 and 26 supro.

Ibid.
} 
or determinable future time is agreed upon, the reasoning of the Little Falls Dairy Company case would indicate that the cooperative owes a demand debt to its patrons of their pro rata interests in the accumulated patron's net proceeds of sales. The stipulation sometimes found that the cooperative will pay the patron at its option would appear to be too indefinite and uncertain to change the demand debt to one payable at a determinable future time. Something more definite than the future whim of the debtor would appear to be necessary to defeat the demand rights of the creditor-patron. ${ }^{38}$

The Royal Commission on Cooperatives of 1945 in Canada favored the issuance of certificates evidencing demand capital loans, called "loan units," which, however, would have contractual limitations on withdrawal rights to protect the cooperative in its capital needs, similar to the withdrawal limitations on some building and loan investment stock in this country. ${ }^{37}$

The chief objection to certificates of indebtedness is that they appear on the liabilities side of the financial statement and thus indicate a situation of inadequate investment capital. Also, certificates of indebtedness may fall due at a time when their payment may cause serious financial embarrassment and even failure of the cooperative. If such certificates are made assignable they may come into the hands of unfriendly business competitors, to the serious inconvenience of the cooperative.

It is possible, however, by proper by-law provisions, to give to cooperatives an option to pay upon call and to set the due date of loan certificates far enough in the future so that the revolving-fund principle may be safely carried on with this type of loan security, especially where it is also safeguarded with adequate contractual limitations on withdrawal rights on and after the due date.

\section{Payment by Interim Investament Certificates}

Many cooperatives issue some form of certificates evidencing an interim contribution to the capital of the corporation. These are variously designated as "capital certificates," "interim capital certificates," "revolving fund certificates," or by some other similar terminology. Their terms ordinarily make the holder a capital

${ }^{80}$ Anthony P. Miller, Inc. v. Commissioner, 164 F. $2 d 268$ (C.C.A. 3d r947), held that the delivery by the debtor corporation of negotiable demand notes to the creditor constituted constructive payment of the debt.

${ }^{87}$ Report of the Royal Commisston on Cooperatives 44, §6, and 209-210 (Ottawa, r945). "Withdrawal of shares and sums credited thereon is, however, subject to the following qualifications:

"(3) When a member withdraws from a retail co-operative society the rules provide that his entire investment shall be paid to him within six calendar months after receipt by the society of notice of withdrawal.

"(4) Not more than ro per cent of the capital paid up on January Ist each year shall be withdrawable during that year, except with the consent of the directors, nor exeept with such consent shall any member be entitled to withdraw more than ro per cent of capital standing to his credit while he remains a member.

"(5) Notwithstanding the foregoing provisions, the directors may by resolution suspend withdrawals of share capital, but such suspension shall in all cases be subject to confirmation by the next general meeting, and if not confirmed, the suspension shall cease. No member shall be allowed to withdraw capital during the period of suspension." 
investor similar to a stockholder for a temporary period. These certificates contain provisions for redemption or repurchase upon the revolving-fund plan.

Advantages of this method of capital financing are that it clearly terminates and changes the parol demand loan by the patron of his retained net margins into a definite capital investment in the nature of interim stock in the cooperative.

\section{Payment by Certificates of Equity or Interest}

A third form of interim capital certificate that has found wide usage in California, Utah, and neighboring states is called a certificate of equity or interest. This is the language customarily used in issuing capital certificates of Massachusetts business trusts for the furnishing of trust capital to the business unit.

What legally occurs upon the issuance of this type of certificate to cover the patrons' pro rata share of retained annual net proceeds of sales and savings is that the demand claim of the patron is converted into revolving trust capital of the cooperative corporation. The corporation becomes the trustee of the capital fund in which the patrons are the equitable owners.

A late case which adopts this view is California \& Hawaiian Sugar Refining Corporation $v$. Commissioner. ${ }^{38}$ In discussing the legal relationship between the patrons and the cooperative, the court said:

It thus appears that under the California law the relationship created by the contract in the "passage of title, and the terms of purchase and sale,"-that is from the very beginning-is that of a trust with the members as settlors creating a trust estate for themselves as beneficiaries.

By the so-called contract of sale this sugar cooperative is made a trustee by the members as settlors.

The solution here determined [which allowed the cooperative to recover processing taxes paid under unconstitutional A.A.A. of 1933] provides no unjust enrichment to the cooperative which must return to its members the recovered amount of the illegal tax. ... 39

Evans and Stokdyk state the legal principle as follows:

The membership interest in the assets is ascertainable and is often represented by a certificate of interest, or some other form of acknowledgment. ${ }^{40}$

One of the early decisions which stressed the trustee-beneficiary relationship is Texas Farm Bureau Cotton Association v. Stovall,41 in which the Texas Supreme Court said:

19 163 F. 2d 53 I (C.C.A. 9th 1947), citing with approval Bogardus v. Santa Ana Walnut Growers' Ass'n, 4r Cal. App. 2d 939, 108 P. 2d 52 (1940), in which the court said: ". . . at all times the relationship between the grower member and the local association, and between the local association and the central association, was that of principal and agent, or beneficiary and trustee; that a fiduciary relationship existed which required at all times that these associations account to the grower member for all proceeds received from the sale of walnuts, and required the grower to bear his proportionate share of all losses sustained. ..." Id. at 534 .

${ }^{80} \mathrm{Id}$. at 535 .

${ }^{\circ}$ Frank Evans and E. A. Stokdyk, The Law op Agricultural Cooperattve Marketing 8i (I937).

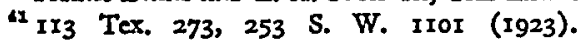


It is true that the grower at all times has a beneficial interest in the net proceeds of this pool [pool of delivered cotton]. . . 42

While a certificate of equity or interest terminates the right of a patron to secure payment on demand, the chief objection to this type of trust-capital arrangement is that the agreement is not ordinarily clear as to the right of the beneficiary or the corporation to terminate the trustee-equitable owner relationship and legally change the position of the patron from that of beneficial owner back again to that of a creditor, who is entitled to receive cash in the redemption or purchase of his trust-capital investment. Redeemable revolving invested capital differs from permanent stock capital in that the parties intend that it shall remain as corporate capital only for an appropriate revolving period and not for the life of the corporation.

\section{Allocation of Patronage Net Margins}

Another method of securing capital by cooperatives is for the corporation to retain a portion of the patronage net margins and give a book credit and notice thereof to the respective patron members. This legally establishes the amount owing by the corporation to the patron, but it does not give the patron any corporate security which can be readily sold or pledged.

This practice has been widely designated, both in Canada and this country, as the "allocation" of patronage net margins. Some persons contend that allocation is merely a unilateral act and is completed when the cooperative makes the computation and the proper entry upon the corporate books without notice thereof to the patron. This, however, does not appear to be a complete allocation. Notice to the creditor of the amount owing to him is necessary before he can report for tax purposes the amount of the credit which the corporation has entered in his favor, and which he can forthwith demand from it unless by a voluntary agreement he makes a term or determinable loan to, or invests with, or agrees to create a trust in such funds retained by, the cooperative.

A leading case in this country which emphasizes the distribution of patronage net margins for tax purposes by "allocation" is San Joaquin Valley Poultry Producers Association v. Commissioner. ${ }^{43}$ In this case the board of directors, under a previous statutory and contract obligation to pay patronage net margins ultimately to members, had established three capital reserves; ( $I$ ) for overpayment, (2) for security of membership fund, and (3) for zoning hazards.

The court held that the marketing cooperative was of an agency-trust type and said:

Petitioner never pretended to be the owner of these sums, but, as required by its by-laws, 'pro-rated' and credited them to its members. The fact that the sums were not payable to the members on demand, or at any fixed time, does not alter the fact that they were their property and not petitioner's. Petitioner held them, not as owner,

sId. at Iro7.

436 F. $2 d_{382}$ (C.C.A. 9th 1943). 
but as agent or trustee for the members. Bogardus v. Santa Ana Walnut Growers Ass'n, supra. Since none of the sums ever belonged to petitioner, they could not be, and were not, income of petitioner.44

The above decision does not determine to what extent the relationship is one of principal and agent or one of trustee and cestui, or whether it was one of agency plus trust in the patronage net margins. It does not determine at what point of time the loan ceases to be a demand loan and becomes a capital loan payable at some determinable future time to the principal, nor when the patron may compel such an accounting and payment. If a trustee-beneficiary relation for certain indicated purposes arises, this case does not indicate when and how the trust may be terminated and the equitable owner may secure the funds. The parties may and should clearly contract with each other regarding these important matters.

The court decided that the undistributed patronage proceeds appearing in the designated reserves were not the income of the corporation. It does not, however, appear that "allocation" was constructive payment to each patron, since the sum was not clearly exigible by him on demand, or at a determinable future time, and he was not given a transferable or pledgeable note or certificate of capital or trust investment.

If it be true, as appears from this decision, that a legal situation may be created such that for some years the annual net proceeds of sales are not taxable either to the cooperative or to the patron, this is a situation which ought to be corrected voluntarily by the cooperatives.

It is a simple and honest thing to issue a cooperative note or investment security against "patronage net margins" annually so that income which is not taxable to the cooperative will be constructively received by the patron and will, therefore, be taxable to him, and so regarded by him. This simply means that, if cooperatives are to put their own houses in satisfactory order regarding the collecting and remitting transactions, allocation, including notice thereof, is not enough. The cooperative should make constructive payment of annual patronage net margins by the issuance of a corporate certificate of indebtedness or some form of capital security to convert retained patronage margins into an interim loan or investment or trust capital in the corporation; or pay in cash upon demand of the patron. Loan capital, if exigible on demand, should be subject to withdrawal safeguards to insure the financial stability of the cooperative.45

\section{Patronage Net Margins Susceptible of Arlocation}

Unfortunately, a few cooperatives have accumulated a capital fund, usually under the heading of "contingent reserve" or some similar designation, without issuing any preferred stock or hybrid security to their patrons and without making complete allocation of the fund or an agreement as to time of payment in cash. These

4I. at 385 .

"Rhodes v. Little Falls Dairy Co., Inc., 245 N.Y.S. 432; see also Texas Certified Cottonseed Breeders' Ass'n v. Aldridge, I22 'Tex. 464, 61 S.W. $2 d 79$ (1933). 
cooperatives have simply retained for capital uses the final payment due from accumulated net proceeds of sales without even bothering to compute the prorated amounts due to the patrons following the close of the fiscal year.

The United States Tax Court in the very liberal memorandum decision of Milk Producers Association of Central California v. Commissioner ${ }^{40}$ held, in 1943, that even without allocation, where accurate and complete records were kept, from which each patron's pro rata interest in net margins could be allocated, and where the cooperative was obligated to operate at cost and ultimately pay patronage net margins to its patrons, no taxable income accrued to the cooperative.

The Tax Court, relying upon the reasoning in the San Joaquin case, held that it was immaterial that allocation had not been made. The court said:

The amounts in question were credited to the general retains account in terms of dollars and cents, and accurate records were kept for each member, showing the amount of butterfat delivered by each member, to the corporation. Therefore, it required only a mathematical computation to determine at any time the interest of each individual member of the General Retains Account. The liability to the members was present and existing, and the method adopted by the petitioner to show that liability on its books could in no way, nor, in fact, did it in any way lessen the amount of that liability.47

It will be observed that the Tax Court analyzes the relationship as that of a trustee-agent-debtor to his beneficiary-principal-creditor. It mentions "the interest of each individual member in the retains account" without elaborating upon the remitting transaction from the point of view of a trustee-beneficiary relationship. While the court did decide that the corporation did not have income for tax purposes, it is a practical impossibility to regard this situation as one of factual constructive payment to the patron who was not even aware of the amount of patronage net margins due to him. Again, criticism of incomplete accounting and remitting seems justified unless annual income is made clearly taxable to someone, either to the cooperative or to the patron. The situation of net patron refunds only susceptible of allocation is, therefore, unsatisfactory and should be scrupulously avoided.

\section{Conclusion}

The foregoing discussion and citations fully support Mr. Stokdyk in his conclusion that the methods of converting retained patrons' funds into loan or invested capital of agricultural cooperatives are confused and unsatisfactory. It is the lawyers, accountants, managers, officers, and directors who must cooperate together to bring order, harmony, and clarity out of this confused situation. If the directors will retain and adequately compensate competent cooperative lawyers, and if lawyers and accountants will cooperate and work together to enact proper by-laws and establish proper practices, then patrons' net proceeds of sales and savings can be converted into revolving-fund capital in such a manner as not to lay cooperatives

4P P-H I944 TC MEss. DEC. SERv. If4, 227.

${ }^{47} 1$ ibid. 
open to the justifiable criticism that annual income is being accumulated which is not legally taxable to the cooperative nor its patrons.

It may take considerable time to induce the great preponderance of cooperatives to pay in cash or to issue to their patrons promptly after the close of each fiscal year preferred stock or revolving-capital certificates or trust-capital certificates of such nature that the patron will readily realize that he has received constructive payment of the patronage net margins due him from the previous year's business. Actual or constructive payment of annual net proceeds of sales should be clearly spelled out in the by-laws and also in the marketing contracts.

The difficulties inherent in this undertaking should not deter anyone from working diligently toward the desired goal. The current criticisms should spur all cooperative officers and professional advisors to eager action. This poses a monumental task. But once the duty is clearly seen, the agricultural cooperators of America can and will simplify, clarify, and standardize their accounting and remitting transactions. In this program cooperators must learn to lean heavily upon those who can give needed professional advice and assistance. 